\title{
HYDROGEN PRODUCTION FOR FUEL CELLS VIA REFORMING COAL-DERIVED METHANOL
}

\section{R03.pdf}

Quarterly Technical Progress Report

Reporting Period Start Date: April 1, 2004

Reporting Period End Date: June 30, 2004

Principal Author: Paul A. Erickson

Report Issue Date: July 2004

DOE Award Number: DE-FC26-03NT41850

Submitting Organization:

The Regents of the University of California, Davis

One Shields Avenue

Davis, California 95616 


\section{DISCLAIMER}

This report was prepared as an account of work sponsored by an agency of the United States Government. Neither the United States Government nor any agency thereof, nor any of their employees, makes any warranty, express or implied, or assumes any legal liability or responsibility for the accuracy, completeness, or usefulness of any information, apparatus, product, or process disclosed, or represents that its use would not infringe privately owned rights. Reference herein to any specific commercial product, process, or service by trade name, trademark, manufacturer, or otherwise does not necessarily constitute or imply its endorsement, recommendation, or favoring by the United States Government or any agency thereof. The views and opinions of authors expressed herein do not necessarily state or reflect those of the United States Government or any agency thereof. 


\section{ABSTRACT}

Hydrogen can be produced from many feed stocks including coal. The objectives of this project are to establish and prove a hydrogen production pathway from coal-derived methanol for fuel cell applications.

This progress report is the third report submitted to the DOE reporting on the status and progress made during the course of the project. This report covers the time period of April 1 - June 30, 2004. This quarter saw progress in five areas. These areas are:

1. External evaluation of coal based methanol and the fuel cell grade baseline fuel,

2. Design, set up and initial testing of the autothermal reactor,

3. Experiments to determine the axial and radial thermal profiles of the steam reformers,

4. Catalyst degradation studies,

5. Experimental investigations of heat and mass transfer enhancement methods by flow field manipulation.

All of the projects are proceeding on or slightly ahead of schedule. 


\section{TABLE OF CONTENTS}

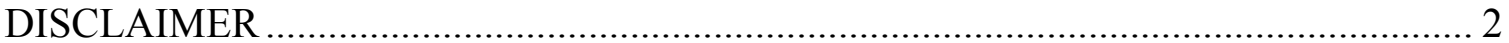

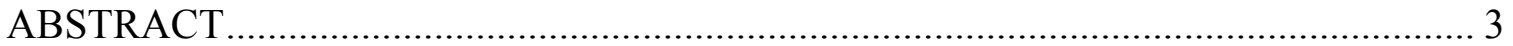

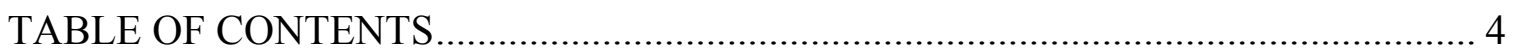

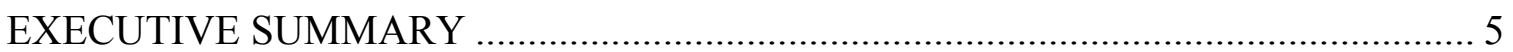

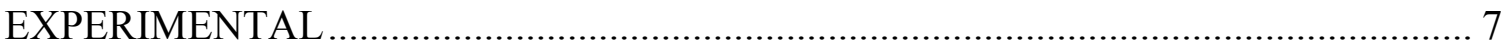

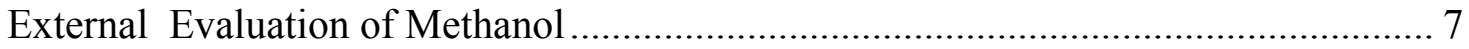

ATR Reactor Design and Construction ............................................................. 7

Thermal Profile Experiments .............................................................................. 9

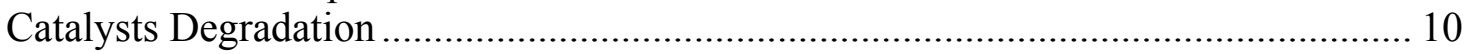

Steam Reformation Enhancement Methods......................................................... 12

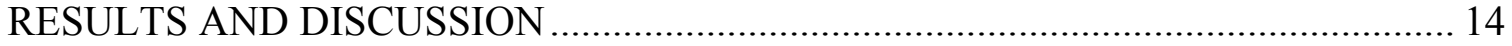

External Evaluation of Methanol ........................................................................ 14

ATR Preliminary Results ................................................................................. 15

Thermal Profile Experimental Results.................................................................. 20

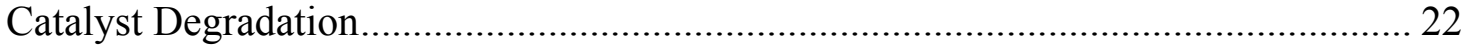

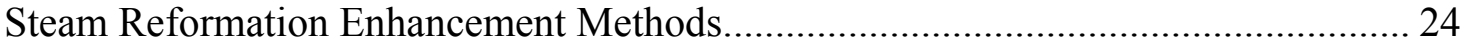

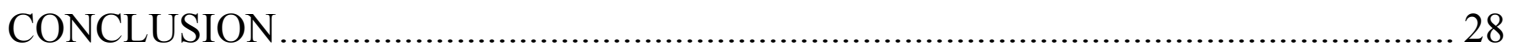

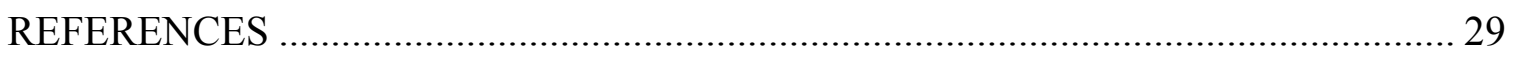




\section{EXECUTIVE SUMMARY}

Hydrogen can be produced from many feed stocks including coal. The objectives of this project are to establish and prove a hydrogen production pathway from coal-derived methanol for fuel cell applications.

This progress report is the third report submitted to the DOE reporting on the status and progress made during the course of the project. This report covers the time period of April 1 -June 30, 2004.

Much progress has been made on the project funded by the Department of Energy during this reporting period. All of the projects are proceeding on or slightly ahead of schedule. This quarter saw progress in five areas. These areas are:

1. External evaluation of coal based methanol and the fuel cell grade baseline fuel,

2. Design, set up and initial testing of the autothermal reactor,

3. Experiments to determine the axial and radial thermal profiles of the steam reformers,

4. Initial catalyst degradation studies with steam reformation,

5. Experimental investigations of heat and mass transfer enhancement methods by flow field manipulation.

The second round of external methanol evaluation is complete. The second round of test results showed a similar order of magnitude for the coal-based and the fuel cell grade methanols regarding chlorides and sulfur.

Construction of the autothermal reformer (ATR) is now completed and preliminary testing has begun. The initial tests have begun with a catalytic converter grade catalyst to validate the test procedures and to give the research team valuable experience with analyzing both the data and control schemes. Once start-up, operation and shut-down procedures have been tested and validated, data collection will proceed using a specially designed proprietary catalyst specifically designed for autothermal reformation.

Further investigations into methods of enhancing the heat transfer characteristics were also performed. Additionally, catalyst degradation studies have begun using coal-derived methanol.

Steam reformation of coal-derived methanol continues. Due to a careful evaluation of the steam reformer temperature profile it was determined that significant sheath conduction from the wall was biasing the temperature measurements close to the reactor wall. A new thermocouple design utilizing a miniature sheath embedded into an external housing with insulating material was tested. This new thermocouple design had more reliable results than the standard design for determining an accurate temperature profile. This new thermocouple design is being implemented throughout the reactor and also into the ATR reactor. 
Data has been collected showing enhancement of heat transfer and mass transfer by bluff bodies. This data is being analyzed and is being expanded to include an empirical model of the enhancement process. Several packing densities are being evaluated in steady state with the bluff bodies. Results are very encouraging to the research team and show significant enhancement of conversion.

In addition to the above projects catalyst degradation projects have been started. The catalyst degradation study will monitor conversion while operating in steady state for the two methanol fuels. This catalyst degradation study will expand as data become available.

Several projects are scheduled for the next quarter including further ATR reactor development and testing, continued evaluation of coal-based methanol in the steam reformers, validation of heat transfer enhancement methods by use of bluff bodies and measuring catalyst degradation using the various methanols. A trip to the DOE sponsor is being planned for September to present the annual results. 


\section{EXPERIMENTAL}

The following section describes the experimental methods used and developed during the reporting period for the following areas: external evaluation of methanol, autothermal reactor design and construction, thermal profile experiments, catalyst degradation, and steam reforming enhancement methods.

\section{External Evaluation of Methanol}

Severn Trent Laboratories - Mobile (STL-Mobile) has performed the $2^{\text {nd }}$ round of the external blind analysis comparing the fuel cell grade methanol to the coal-derived methanol. The analysis covered the amounts of total sulfur and chloride. For the $1^{\text {st }}$ round external analysis, chloride and sulfur showed suspicious results. Chloride in the coal-derived methanol showed 100 times greater than in fuel cell grade methanol. A $2^{\text {nd }}$ sample set was sent to STL-Mobile to verify the results, which are reported below in the Results and Discussion section.

\section{ATR Reactor Design and Construction}

The ATR reactor is complete and has been tested using catalyst from an automobile catalytic converter. The reactor includes 12 ports along the side of the reactor for measuring temperature and/or pressure. 4 different end caps were manufactured for versatility in testing (see Figure 1 below).

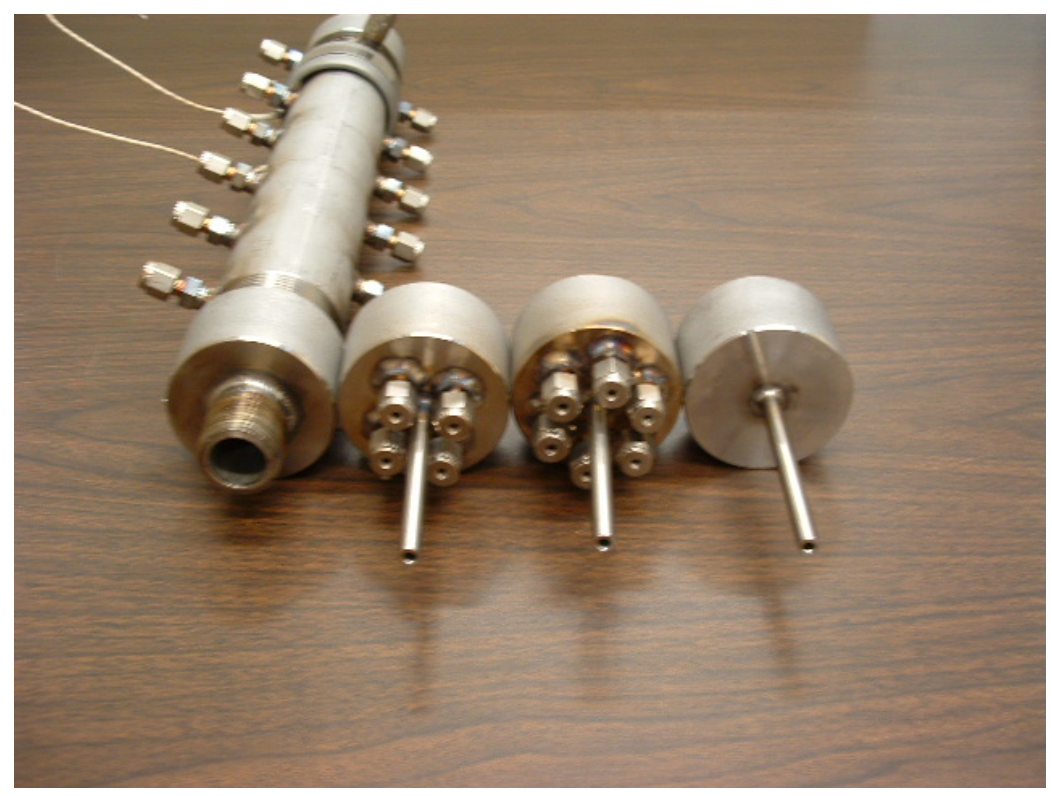

Figure 1: ATR reactor and 4 different end caps (from left to right: acoustic adapter, 4-thermocouple ports, 6-thermocouple ports, regular connection end cap) 
The air heater for the air supply subsystem is also complete (see Figure 2). The air heater was originally fitted with a 5", 400W cartridge heater which proved insufficient for heating air to $300^{\circ} \mathrm{C}$. Therefore a 9-1/2", $525 \mathrm{~W}$ cartridge heater was installed for better performance. The air heater pipe was also filled with $1 / 8$ " aluminum rod that was cut into small, $\sim 1 / 8$ ", lengths to aid in heat transfer.

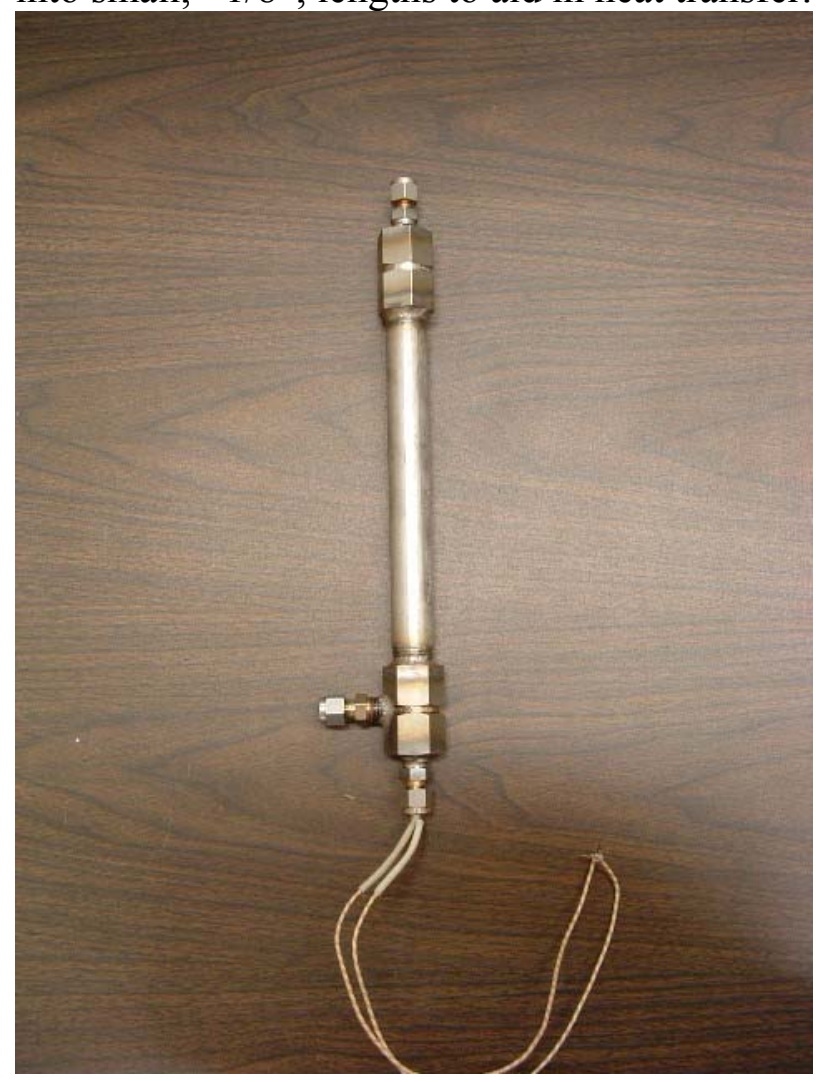

Figure 2: Air heater for air supply subsystem

A second Omega 1900-series mass flow controller (MFC) with a range of 0-10 SLPM is being ordered to increase the range of testing for the ATR reactor. Thermocouples that were specially manufactured for insertion into the monolith substrate were damaged due to thermal cycling and are being redesigned. Preliminary testing will continue with fuel cell grade methanol and various catalysts. Operating procedures for the ATR reactor are in progress and nearly complete.

For the static pressure monitoring of the autothermal reactor, Kulite Semiconductor Products, Inc donated a Kulite WCT-250 water-cooled pressure transducer to support this research. This water-cooled pressure transducer can handle high temperature gas up to $700{ }^{\circ} \mathrm{C}$ and is able to monitor the high temperature steam reformate inside the reactor.

Also, a NI 6733 High-Speed Voltage Output board and a NI SCB-68 Shielded Connector Block were purchased from National Instrument Inc. This 8 channels analog voltage output board is used to send the commanding signals of 2 micro gear pumps, 2 air flow meters, and also the exciting voltage of the pressure transducer. It left three extra channels, which allows expending the whole system for further use. 


\section{Thermal Profile Experiments}

Thermal profile measurements elucidate the limiting factors in reactor design, can be used to diagnose catalyst degradation and offer insight into the effectiveness of reactor design changes. Recent work has identified conduction of heat down the axial thermocouple sheath as a significant source of error in thermal profile measurements. Sheath conduction causes the thermocouple measurements to deviate from the true gas temperature when large radial thermal gradients exist. Large thermal gradients can exist in small diameter reformer reactors and these thermal gradients increase with increasing flow rate and increasing reaction rate.

Using standard 1/16' thermocouple probes the sheath conduction effect was measured by traversing the probe tip all the way from the opposite wall of the reactor to the near wall of the reactor, see Figure 3. Differences in the measurements on the far side if the reactor and the near side of the reactor are caused by sheath conduction. On the far side of the reactor the true gas temperature is higher than the measured temperature due to sheath conduction away from the hot region near the wall towards the cooler centerline of the reactor. On the near side of the reactor the true gas temperature is lower than the measured temperature due to sheath conduction from the hot region near the wall towards the cooler centerline of the reactor. Very close to the near wall the true gas temperature is most likely higher than the measured temperature due to sheath conduction away from the hot region along the inside wall to the cooler region inside the thermocouple port. 


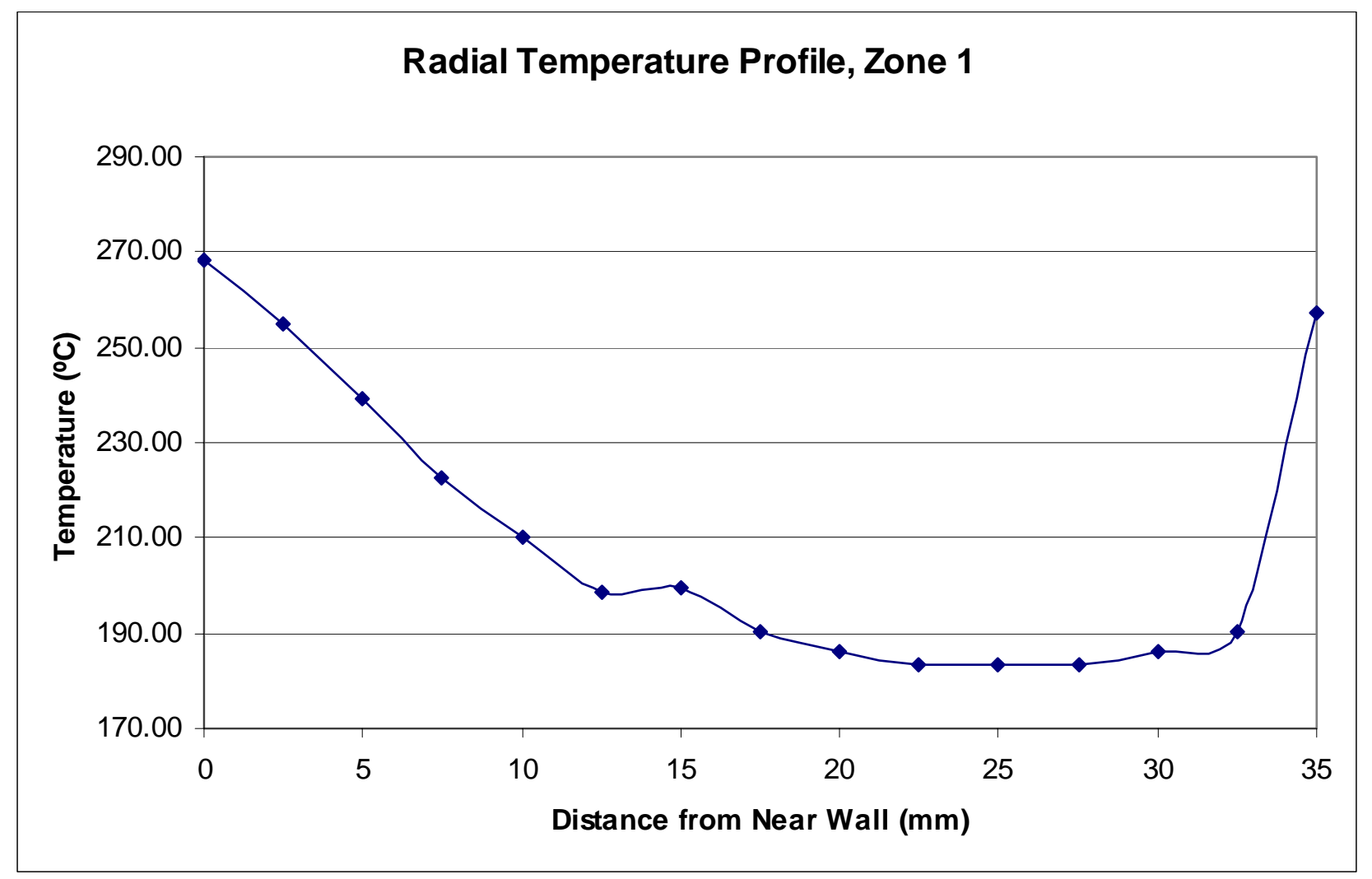

Figure 3 : Radial Temperature Profile of the full diameter of the reactor. Differences between the near side and far side are partly caused by sheath conduction

Strategies were developed for reducing the axial conductivity of the thermocouple probes including using ceramic sheath materials or using very fine gage thermocouple probes. The ceramic sheath materials proved to be too brittle for the traverse technique and were deemed impractical. The use of fine gage thermocouples is complicated by their low flexural strength. Protecting the fine gage thermocouples with a thermally isolated support tube is the current iteration in this development process. The fine gage thermocouples are inserted into stainless steel support tubes and the support tube is then filled with a thermally insulating ceramic adhesive. A one half inch section of bare thermocouple wire protrudes from the support tube inside the reactor allowing the higher surface to cross-sectional area of the smaller probe to greatly reduce the effects of sheath conduction.

\section{Catalysts Degradation}

The possibility and theoretical background of catalyst degradation was mentioned in previous report.

Temperature gradient (See Figure 4) inside the reactor can be caused by heat and mass transfer limitation as well as difference of response time due to power demand during the process of producing hydrogen throughout the reactor. However, either catalyst 
degradation or secondary reaction inside the reactor might be stirred up by temperature gradient inside the reactor. Figure 4 shows heat flow and expected resulting reactor temperatures in a steam reformer.

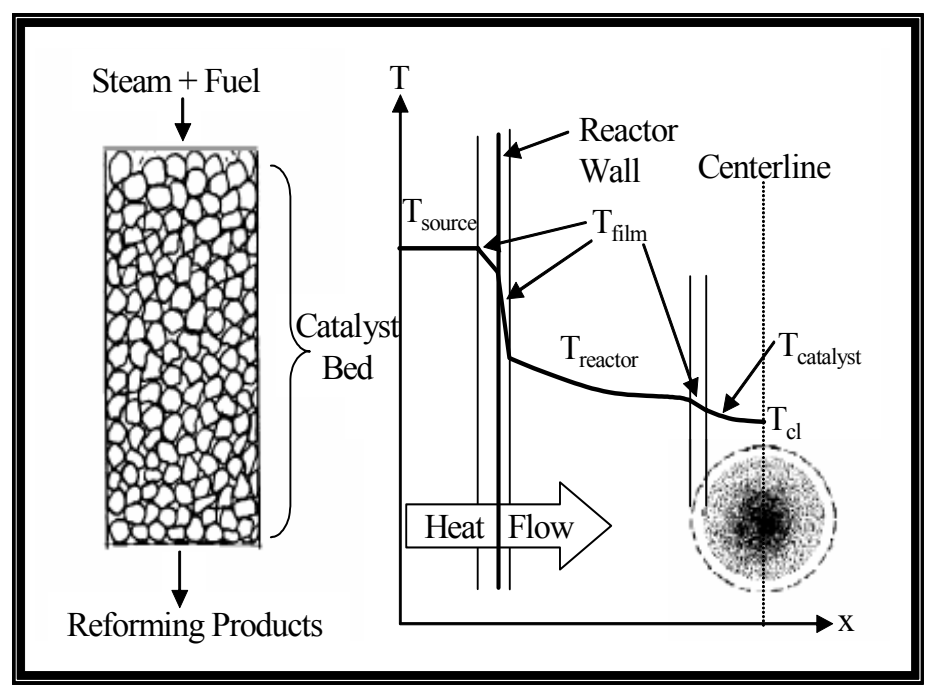

Figure 4 Heat flow and expected resulting reactor temperatures in a steam reformer

Temperature gradient inside the reactor could be minimized by means of another heat source from the center of reactor. On the other hand, reactor volume could be smaller than the other reactors due to internal cartridge heater so that secondary reaction pathway (i.e. unexpected by-product), which could happen due to temperature gradient inside the reactor, should be reduced. Both preconditions could be sufficient for evaluation of different types of fuels in terms of catalyst degradation and fuel efficiency. Consequently, internal cartridge heater in the center of reactor can meet the requirements to evaluate fuel quality as well as investigate catalyst degradation to compare coalderived methanol with chemical grade methanol. 


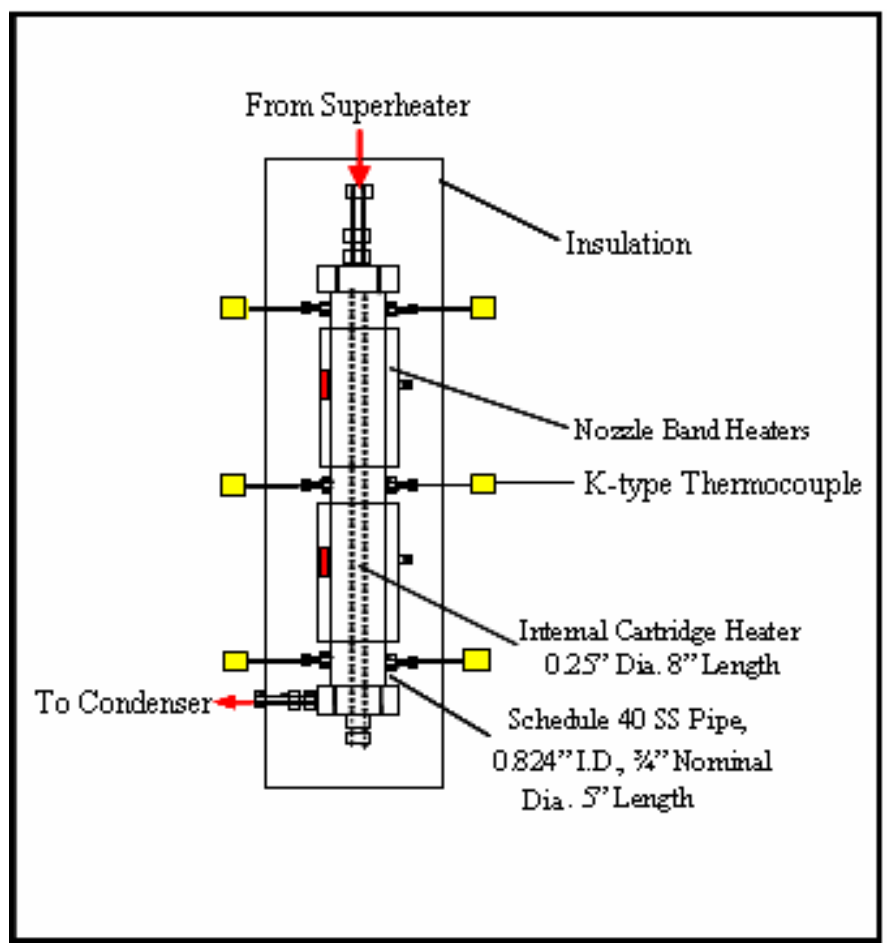

Figure 5 Schematic of Reactor with Internal Cartridge Heater

Figure 5 shows schematic of reactor with internal cartridge heater. It is called as Reactor C. The housing material for reactor was a $12.7 \mathrm{~cm}$ (5 in) stainless-steel pipe (nominal $3 / 4$ in Dia., schedule 40) threaded at both ends. The under cap was machined to adapt a $0.635 \mathrm{~cm}(0.25 \mathrm{in})$ MNPT fitting on the side as well as on the bottom to make gas pathway and place internal cartridge heater inside the reactor. 2 nozzle band heaters $(2.5$ $\mathrm{cm}$ (1 in) I.D., $5.1 \mathrm{~cm}$ (2 in) width), each with a $120 \mathrm{~V}, 275 \mathrm{~W}$ rating were used for external heating. Furthermore, internal cartridge heater (0.25in Dia. 8 in length), with a $120 \mathrm{~V}, 600 \mathrm{~W}$ rating was also applied to this reactor. Reactor surface was wrapped with aluminum tape with high thermal conductivity to increase heat transfer from the nozzle band heaters to the reactor. Six $0.159 \mathrm{~cm}$ (0.0625 in) Dia. stainless-steel-sheathed, ungrounded K-type thermocouples were applied to monitor temperatures inside the reactor at each zone. In addition, three $0.0508 \mathrm{~cm}$ (0.020 in) Dia.: ungrounded K-type thermocouples was used for controlling reactor exterior surface temperature between the nozzle heater band and the exterior wall of reactor. Six $0.32 \mathrm{~cm}(0.125 \mathrm{in}) \mathrm{MNPT}$ to 0.32 $\mathrm{cm}(0.125 \mathrm{in})$ pipe fittings by Swagelok were used for holding the six thermocouples. Moreover, to block leak throughout thermocouple and be reusable, graphite ferrules was used instead of stainless steel ferrules. Insulation for the reactor was composed of a 3 " thick calcium silicate material with a temperature tolerance of $649^{\circ} \mathrm{C}\left(1200^{\circ} \mathrm{F}\right)$.

\section{Steam Reformation Enhancement Methods}

In the $2^{\text {nd }}$ quarter report, the steam reformation enhancement study took the experiments using 2-pack length density of bluff body with crushed and pelletized catalysts inside reactor $\mathrm{B}$. The result showed an improvement in fuel conversion for $5 \%$ comparing to 
one without bluff body inside reactor B. According to these pre-run results of 2 packages of bluff body, a factorial experiment had been designed and now under investigating the influence of package numbers of bluff bodies inside the reformate pathways of a steam reforming reactor and its interaction with catalyst dimension and space velocity. The experimental factors description (independent variables) chosen for this study includes:

X1 (Factors 1): Bluff Bodies package density inside the reactor. Two levels of bluff body package density will be examined for this study. ( 8 packages per 7.5 inch for high level and 2 packages per 7.5 inch for low level.)

$\mathrm{X} 2$ (Factors 2): Catalyst dimension. The catalyst dimensions can determine the reacting surface of the reforming process. A crushed catalyst of average length: $0.25 \mathrm{~cm}$ is used as a low level. An average diameter of $0.47 \mathrm{~cm}$ thickness provided by the manufacture is used as a high level.

X3 (Factor 3): Flow rate. Each experiment will run for four flow rate (represent for four liquid-hourly-space-velocities) for $5 \mathrm{ml} / \mathrm{min}, 10 \mathrm{ml} / \mathrm{min}, 15 \mathrm{ml} / \mathrm{min}$ and $20 \mathrm{ml} / \mathrm{min}$.

$5 \mathrm{ml} / \mathrm{min}$ will be chosen as low level and $20 \mathrm{ml} / \mathrm{min}$ as high level.

The factors and corresponding levels are tabulated in Table 1.

Table 1 - Factors and Levels

\begin{tabular}{lll} 
Factors (inputs) & Low level: $(-)$ & High level: $(+)$ \\
\hline X1 (Flow rate) & $5 \mathrm{ml} / \mathrm{min}$ & $20 \mathrm{ml} / \mathrm{min}$ \\
X2 (Catalyst dimension) & Crushed $(0.25 \mathrm{~cm})$ & Pelletized $(0.47 \mathrm{~cm})$ \\
X3 (Package density) & 2packs & 8 packs
\end{tabular}

The input matrix and run orders designed for this factorial experiment is tabulated in Table 2.

Table 2 - input matrix and run

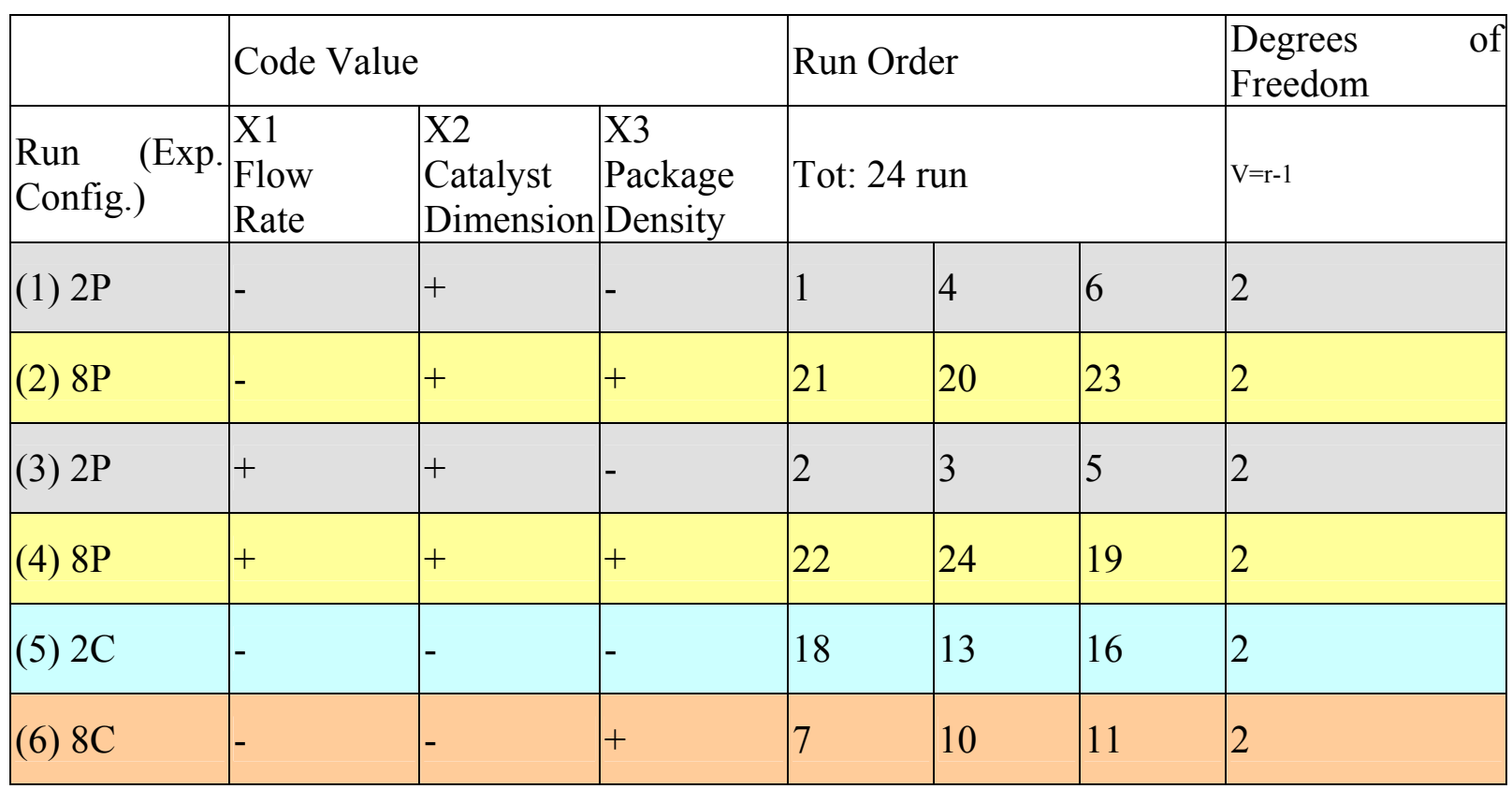




\begin{tabular}{|l|l|l|l|l|l|l|l|}
\hline$(7) 2 \mathrm{C}$ & + & - & - & 15 & 17 & 14 & 2 \\
\hline$(8) 8 \mathrm{C}$ & + & - & + & 12 & 8 & 9 & 2 \\
\hline
\end{tabular}

This factorial experiment design can help understand the individual effect of each independent variable and also the interaction of multi variables via the statistical analysis. It can also develop a statistical model to predict the conversion according to the independent variables used in the experiment.

\section{RESULTS AND DISCUSSION}

The following section presents results from the reporting period from the following areas: external evaluation of methanol, preliminary autothermal reformation of fuel cell grade methanol, thermal profile experiments, catalyst degradation, and steam reforming enhancements methods.

\section{External Evaluation of Methanol}

STL-Mobile used different methods to measure the sulfur content for the $1^{\text {st }}$ and $2^{\text {nd }}$ rounds of the external analysis. Table 4 shows coal-derived methanol has $20 \mathrm{mg} / \mathrm{kg}$ more chloride than fuel cell grade methanol rather than $15850 \mathrm{mg} / \mathrm{kg}$ more chloride shown in Table 3.

Table $3-1^{\text {st }}$ round External Analysis of Coal-Derived Methanol and Fuel Cell Grade Methanol

\begin{tabular}{|l|l|l|}
\hline & $\begin{array}{l}\text { Coal-derived } \\
\text { Methanol }\end{array}$ & $\begin{array}{l}\text { Fuel cell grade } \\
\text { Methanol }\end{array}$ \\
\hline Ethanol(mg/l) & $<8000$ & $<8000$ \\
\hline Methanol(mg/l) & 740000 & 750000 \\
\hline Water $(\%)$ & $0.02 \%$ & $0.11 \%$ \\
\hline $\begin{array}{l}\text { Total Petroleum } \\
\text { Hydrocarbon(mg/l) }\end{array}$ & 17 & 5.9 \\
\hline Chloride(mg/kg) & 16000 & 150 \\
\hline Sulfur(mg/kg) (ASTM-D-129-64) & 112 & 298 \\
\hline
\end{tabular}

Table $4-2^{\text {nd }}$ Round External Analysis of Coal-Derived Methanol and Fuel Cell Grade Methanol

\begin{tabular}{|l|l|}
$\begin{array}{l}\text { Coal-derived } \\
\text { Methanol }\end{array}$ & $\begin{array}{l}\text { Fuel cell grade } \\
\text { Methanol }\end{array}$ \\
\hline
\end{tabular}




\begin{tabular}{|l|l|l|} 
Chloride(mg/kg)(EPA 352.2) & 410 & 390 \\
\hline Sulfur(mg/kg) (EPA 375.4) & $<170$ & $<170$ \\
\hline
\end{tabular}

\section{ATR Preliminary Results}

Preliminary testing was conducted with wall temperature set points of $350^{\circ} \mathrm{C}, \mathrm{S} / \mathrm{C}=1.5$, premix flowrate ranging from 1.4 to $8.5 \mathrm{ml} / \mathrm{min}$, and $\mathrm{O} / \mathrm{C}$ ranging from 0.0 to 0.40 . Fuel conversion of greater than $90 \%$ has been achieved using the downstream catalyst from an automobile catalytic converter. The used catalyst has a burnt appearance from reaching temperatures of approximately $480^{\circ} \mathrm{C}$ (see Figure 6 below). Reformate composition was uncertain due to complications with the gas analyzer.

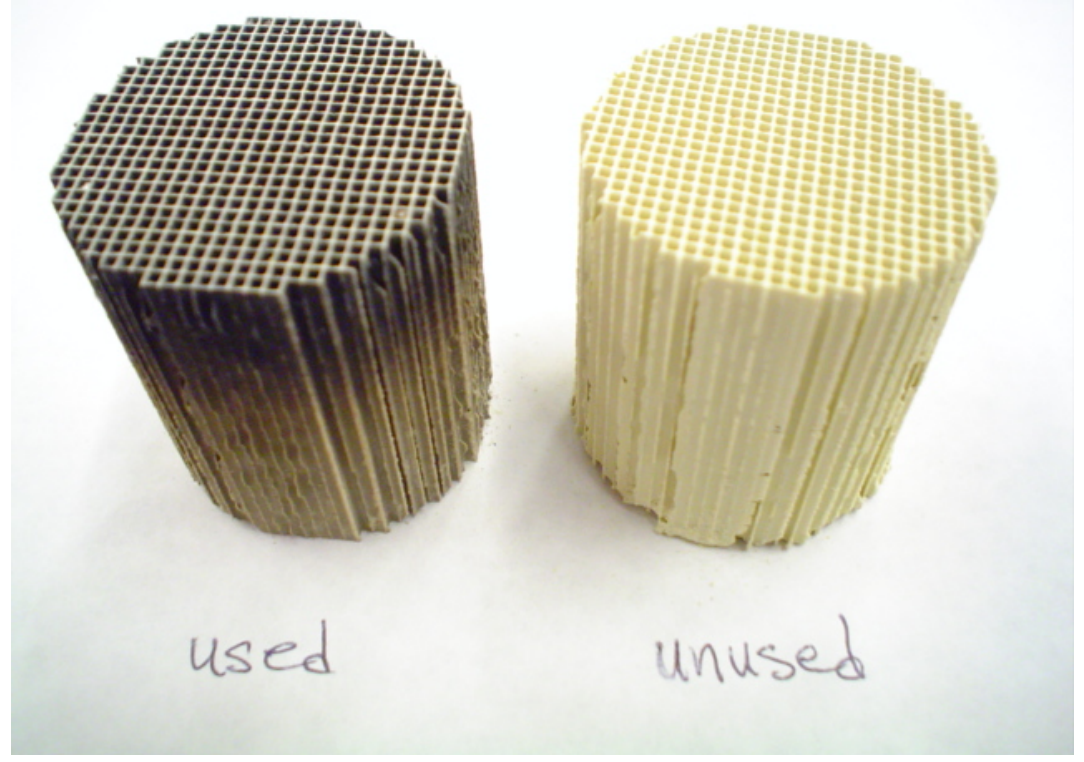

Figure 6: Used and unused catalyst for ATR reactor.

As seen in Figure 7, fuel conversion increases from $17 \%$ at $\mathrm{O} / \mathrm{C}=0$ to $90 \%$ at $\mathrm{O} / \mathrm{C}=0.25$ and then levels off at higher $\mathrm{O} / \mathrm{C}$. The conversion tested at the two different premix flowrates is similar at given $\mathrm{O} / \mathrm{C}$ 's. 


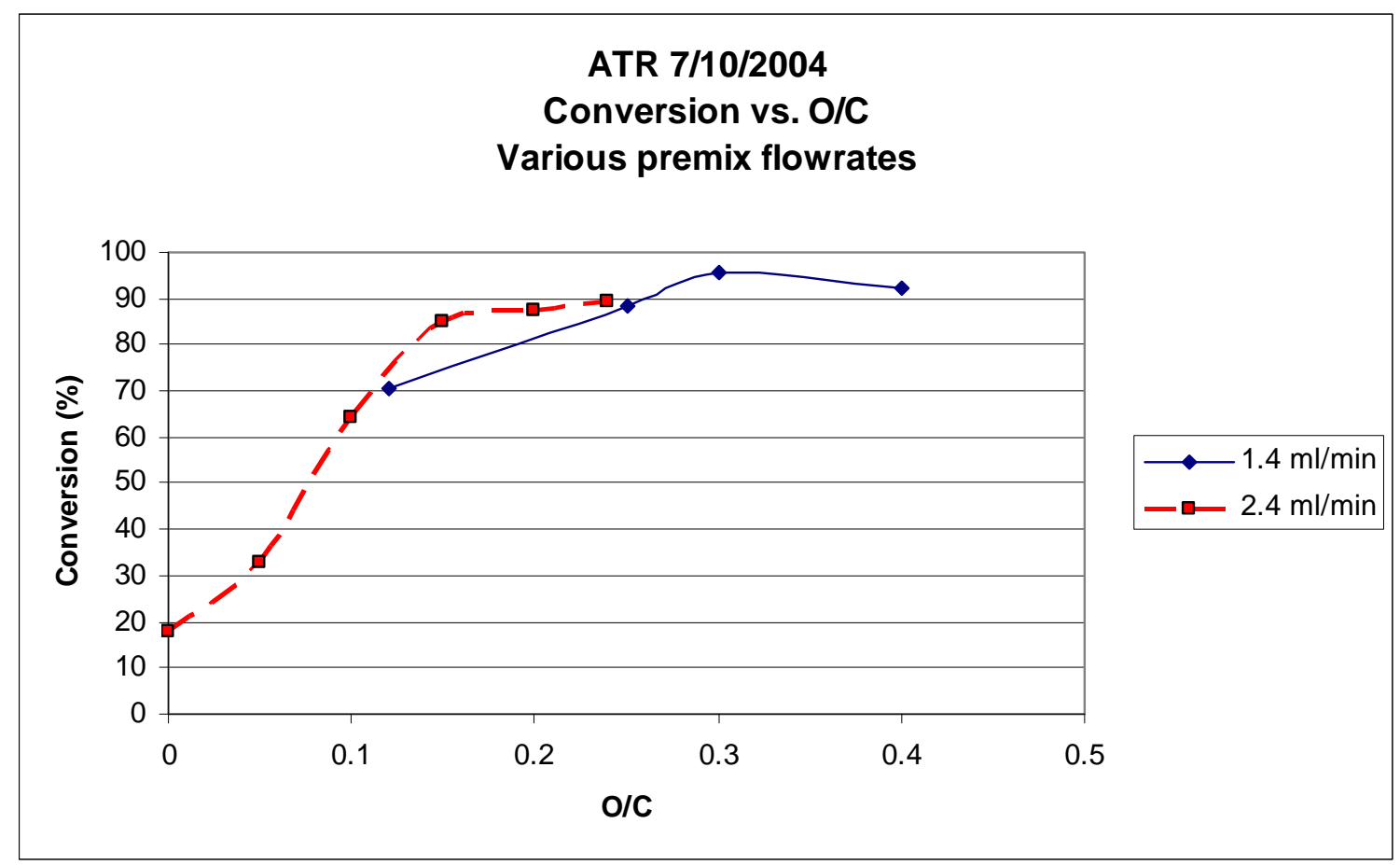

Figure 7: Conversion results in ATR reactor

Conversion should also be dependent on the reactant flowrates. Conversion is fairly constant above GHSV's of $3000 \mathrm{~h}^{-1}$, as shown in Figure 8. Intuitively, the conversion should increase with decreasing GHSV, because the reactants have a longer residence time in the catalyst bed. However, the opposite result is displayed in Figure 8. This may be due to a laminar flow regime at low flowrates, which could affect reactant mixing upstream and therefore decrease the conversion. 


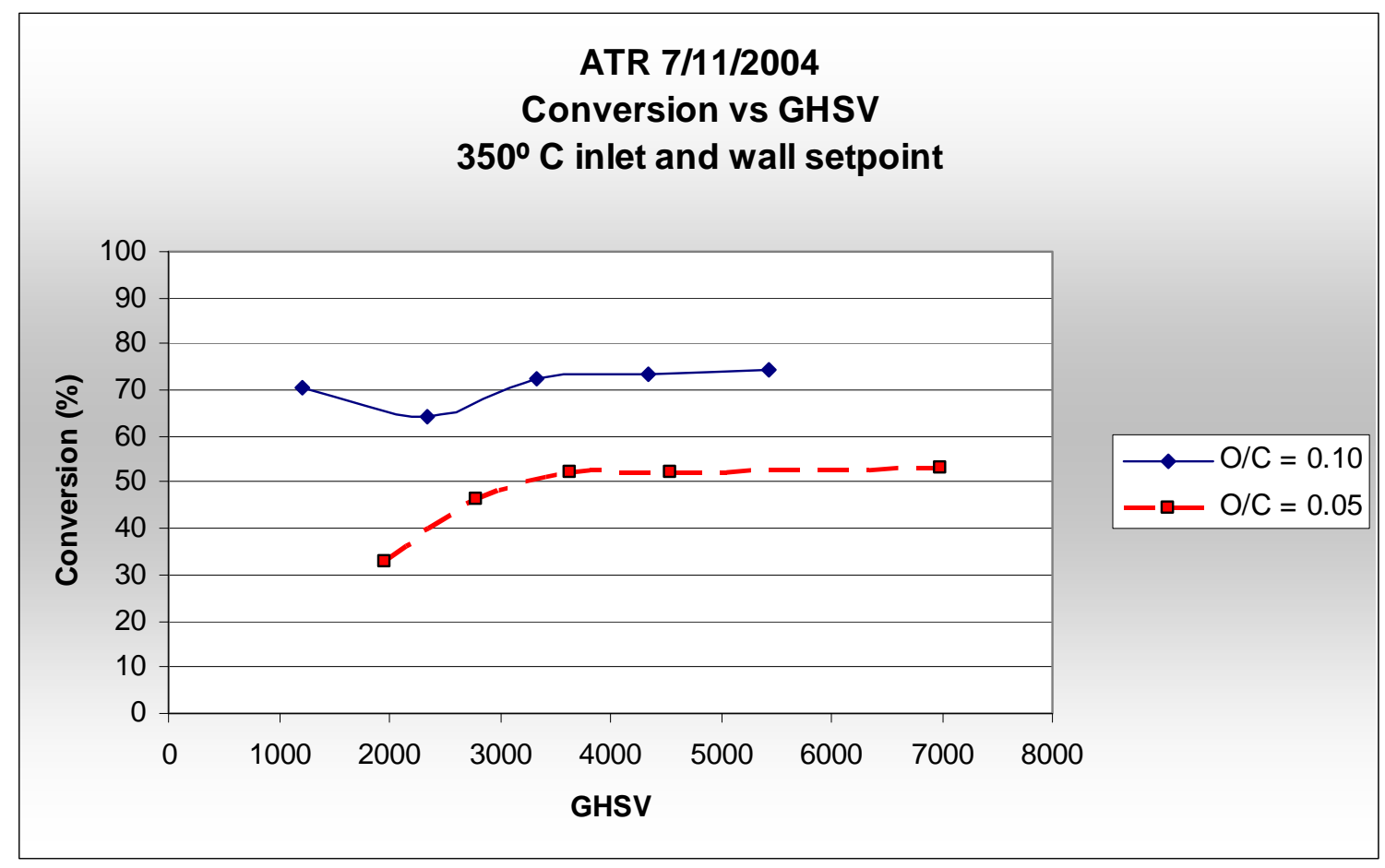

Figure 8: Conversion as a function of gas hourly space velocity.

Catalyst bed temperature increases with $\mathrm{O} / \mathrm{C}$, from $309^{\circ} \mathrm{C}$ at $\mathrm{O} / \mathrm{C}=0$ (steam reforming), to $430^{\circ} \mathrm{C}$ at $\mathrm{O} / \mathrm{C}=0.24$ as seen in Figure 9 below. Temperatures in the catalyst bed are even higher at $\mathrm{O} / \mathrm{C}=0.4$, reaching temperatures of around $480^{\circ} \mathrm{C}$. The reactor has axial zones 1 through 5 and the catalyst was located in zone 4 for the experiments shown. The temperatures displayed in Figure 9 are reactor centerline temperatures, and the catalyst interior temperatures. The catalyst interior temperatures are taken at the same axial length inside the catalyst and represent a radial temperature profile. $\mathrm{O} / \mathrm{C}$ has a significant effect on the catalyst bed temperature and less effect on the reactor center line temperature. This implies that the oxidation reaction of methanol is in fact occurring in the catalyst bed as expected. Zones 4 and 5 show a mild increase in temperature with increasing $\mathrm{O} / \mathrm{C}$. This is because of the hot product gases coming from the catalyst bed. 


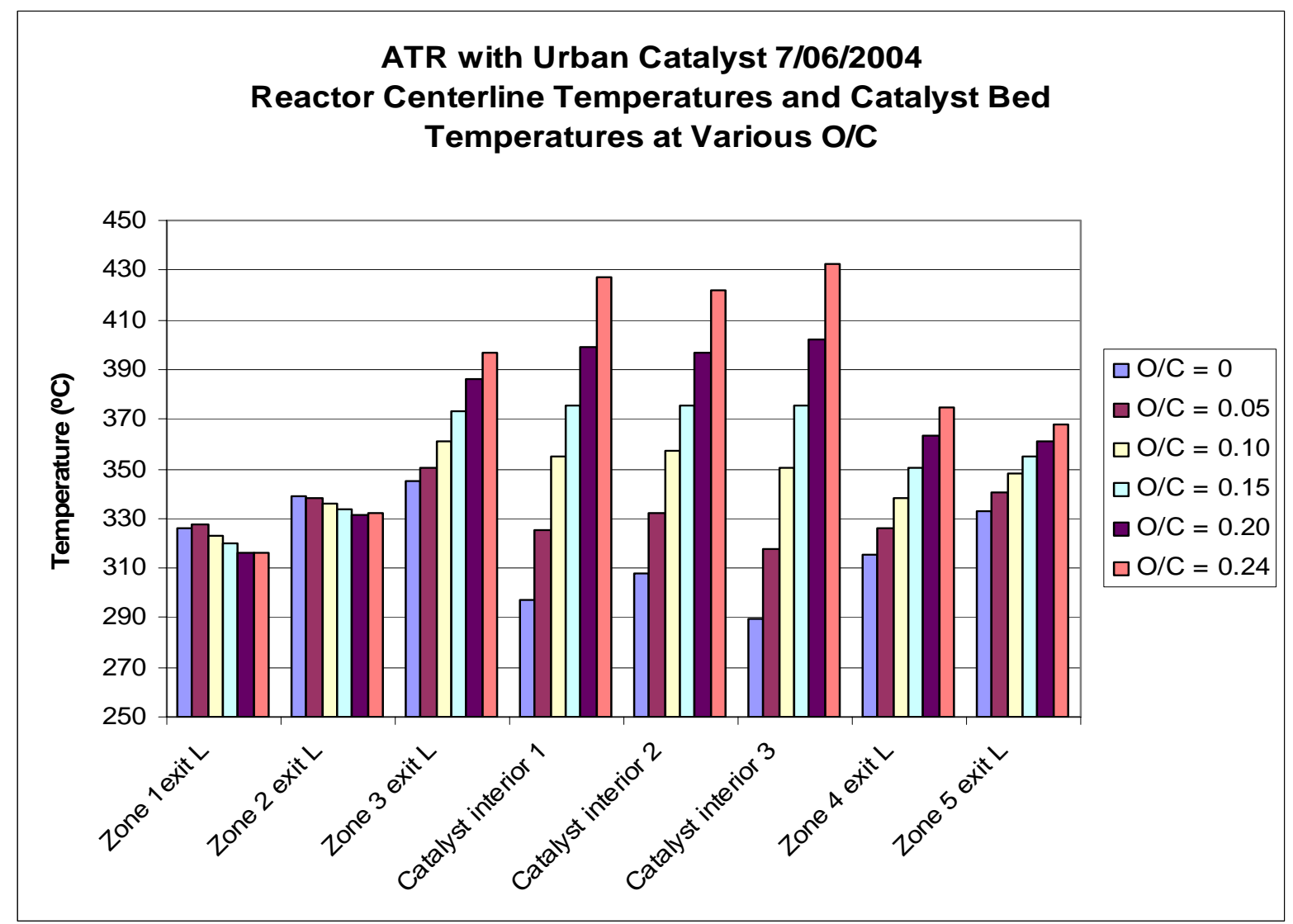

Figure 9: ATR reactor temperature profile at various $\mathrm{O} / \mathrm{C}$.

The temperature response of the catalyst bed to increases in $\mathrm{O} / \mathrm{C}$ is fairly rapid, as shown in Figure 10 below. The catalyst bed temperature rises more rapidly at higher $\mathrm{O} / \mathrm{C}$ ratios. This preliminary experiment is a stepping stone to transient response studies that may be carried out in the future. 


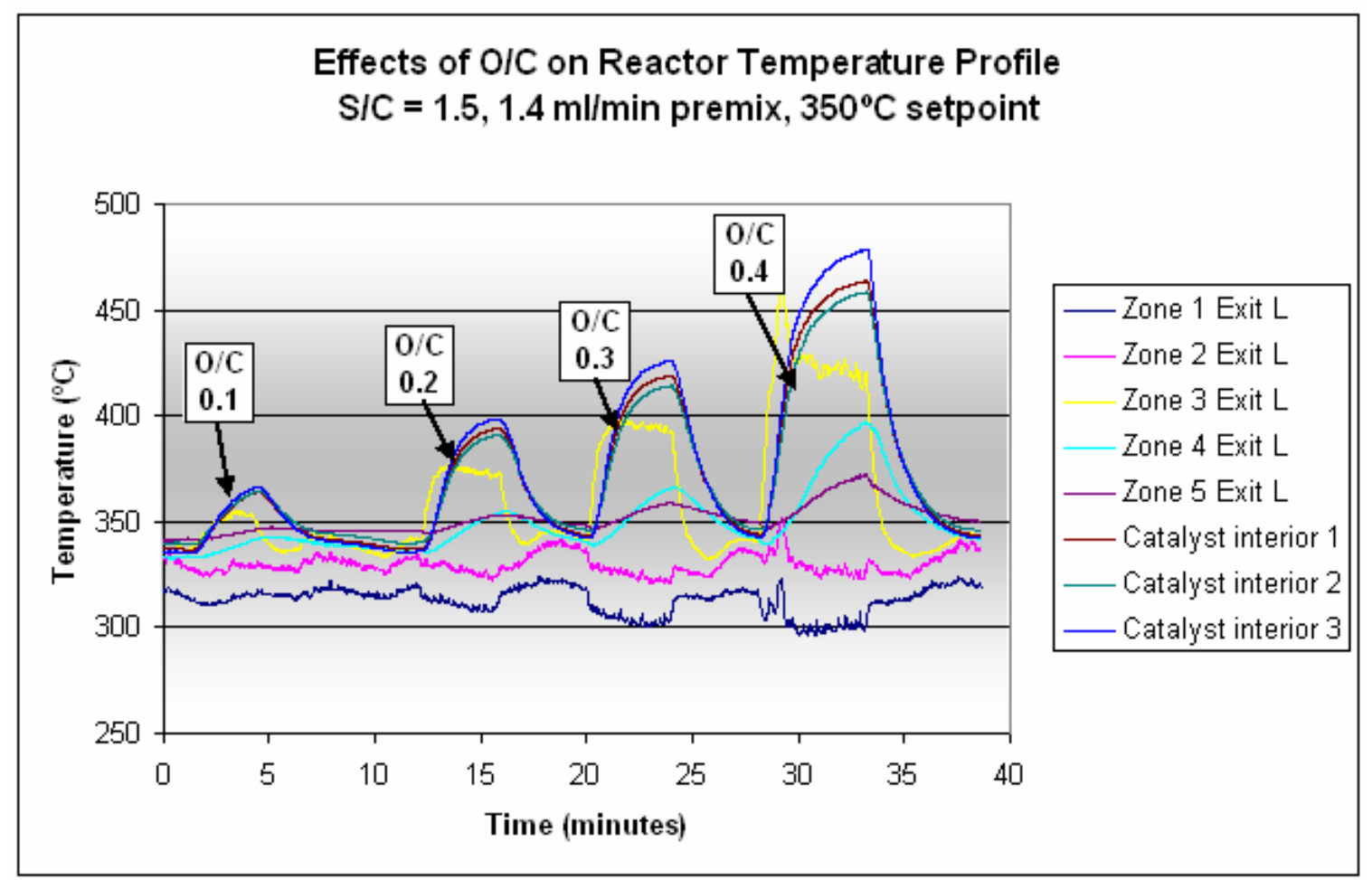

Figure 10: Temperature profile of reactor with oxidant supply pulses for various $\mathrm{O} / \mathrm{C}$.

Fuel conversion is dependant on reactant inlet temperatures and reactor set point temperatures. At $350^{\circ} \mathrm{C}$ inlet and reactor wall temperature set points, the conversion of fuel was $74 \%$, compared to $63 \%$ for set points of $260^{\circ} \mathrm{C}$ as shown in Figure 11 below. 


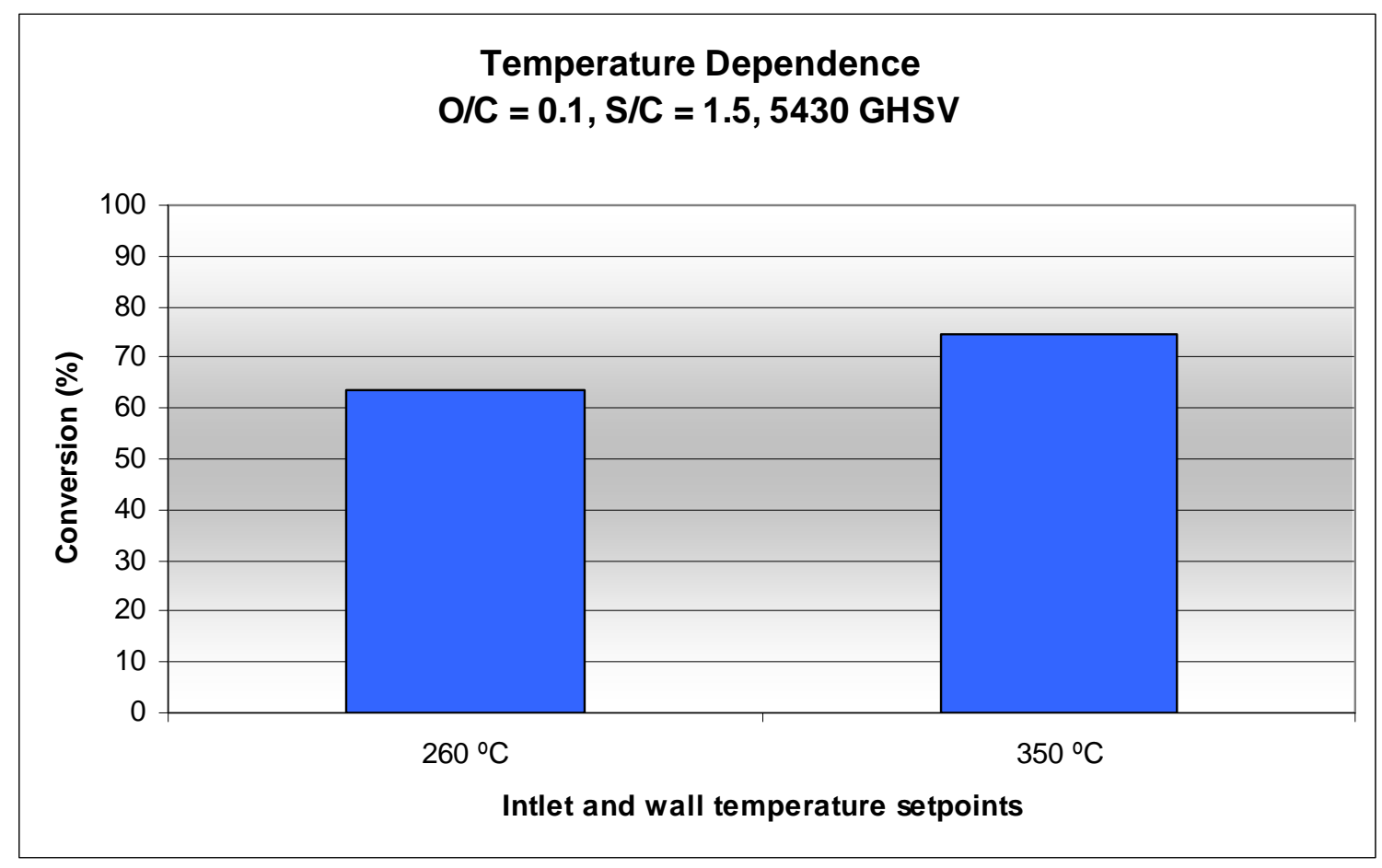

Figure 11: Conversion at two different inlet and reactor temperatures.

ATR experiments are scheduled for early August for an in depth O/C study. Reaction progression through the monolithic catalyst will also be investigated. These are baseline studies which will utilize fuel cell grade methanol as the fuel which will aid in the analysis of reforming coal based methanol.

\section{Thermal Profile Experimental Results}

A preliminary in-situ comparison of the standard probes to two variations of the support tube probe design has been completed showing significantly reduced effects from sheath conduction. This preliminary experiment suggests that the effects of sheath conduction near the outer wall of the reactor may be skewing the measurements by as much as $25^{\circ} \mathrm{C}$, see Figure 12 and Figure 13. Thermocouples of the improved design are currently being fabricated to carry out measurements of a full temperature profile. A complete investigation of the effect of reactor aspect ration and flow rate on the thermal profile is planned. A bench top axial conduction experiment is underway to compare the performance of the different thermocouple types. 


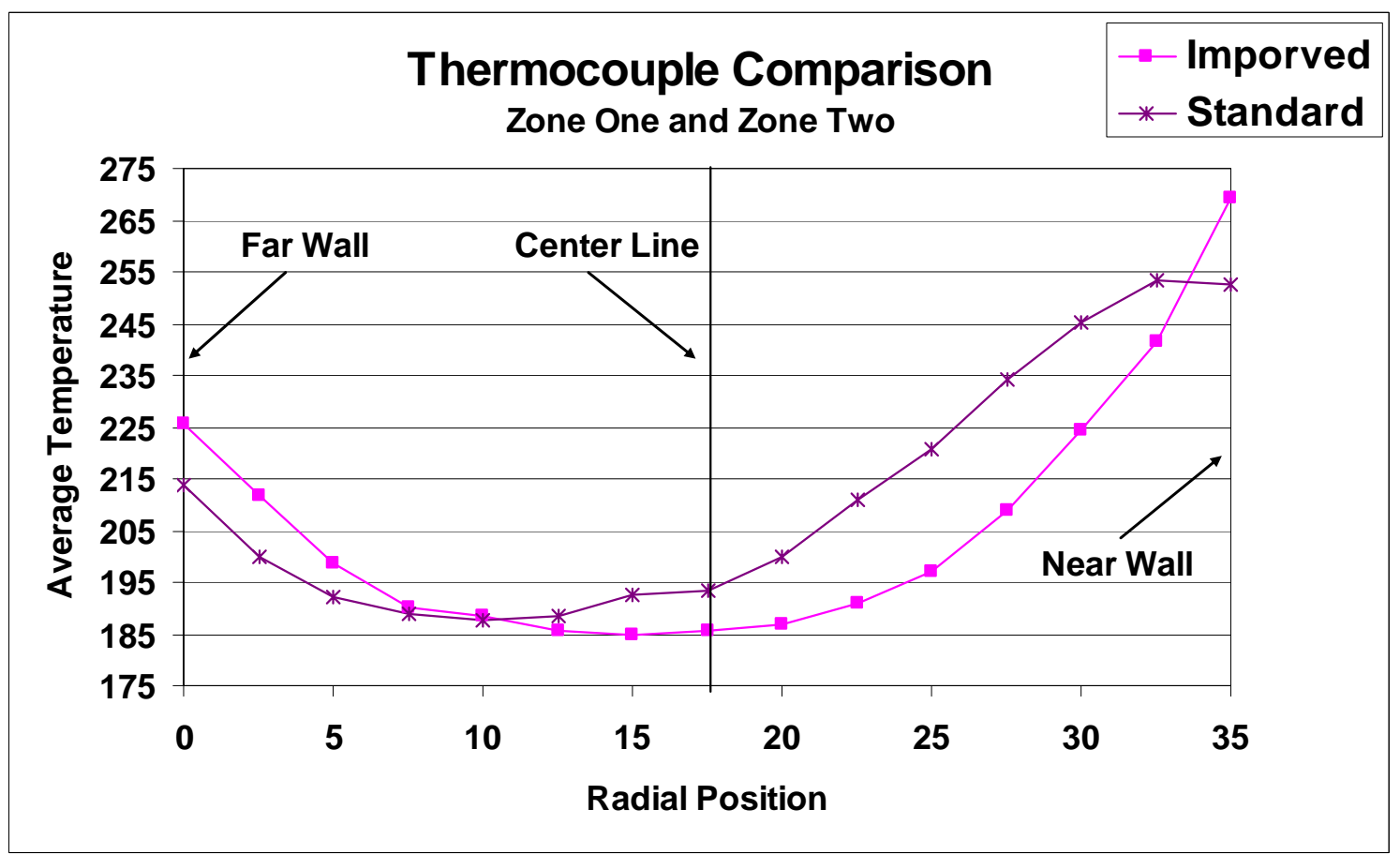

Figure 12: Comparison between standard thermocouples available from OMEGA and improved thermocouples fabricated in house. The two thermocouples are in two different zones of the reactor where the true gas temperature is not exactly the same.

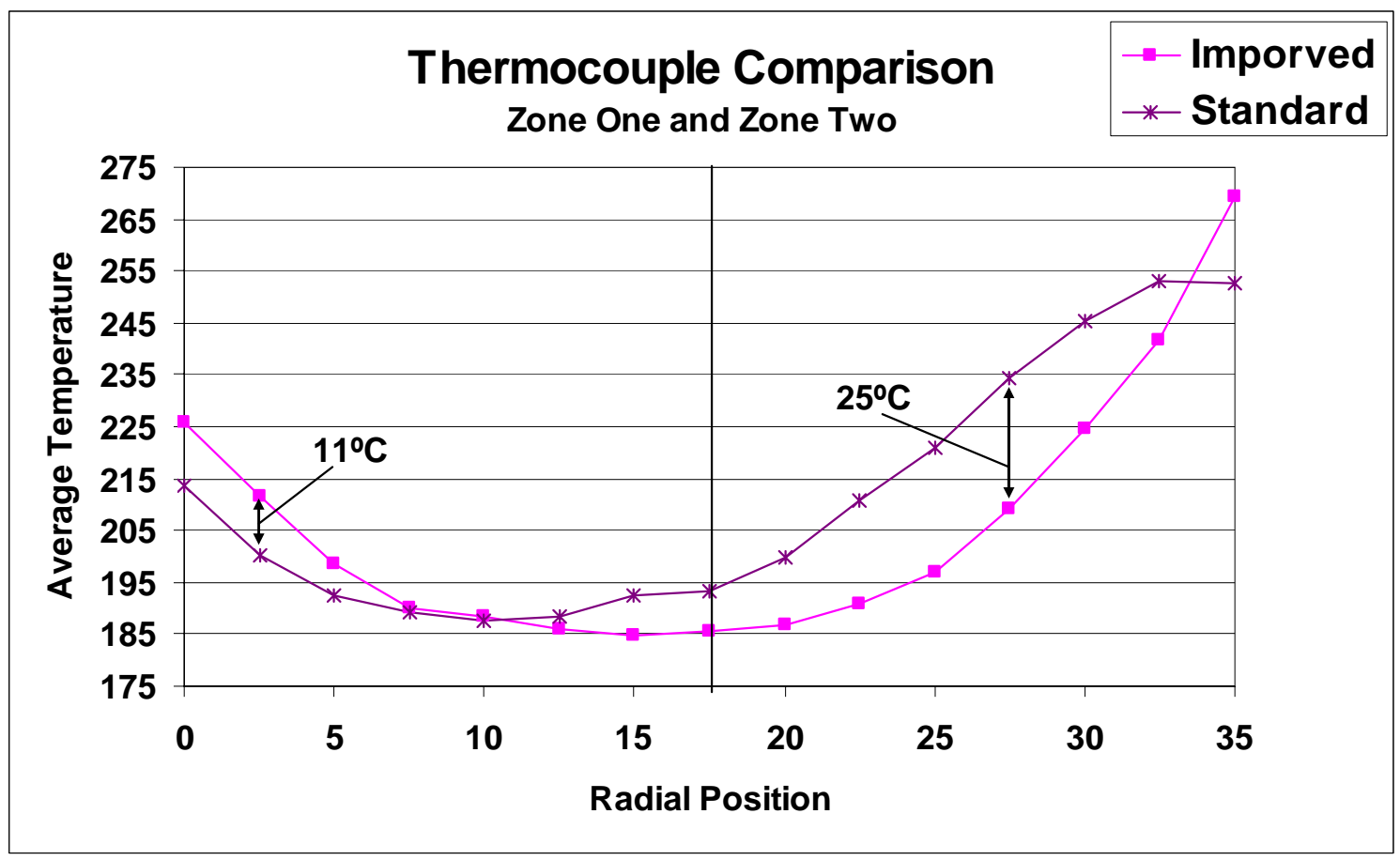

Figure 13 : Temperature differences caused by sheath conduction. 


\section{Catalyst Degradation}

Figure 14 shows overall conversion using coal-derived methanol at different flow rate using $39 \mathrm{~g}$ of crushed catalyst. This experiment was performed using Reactor C. Highest conversion (99.8\%) showed at 2.5 liquid hourly space velocity of methanol (LHSV-M).

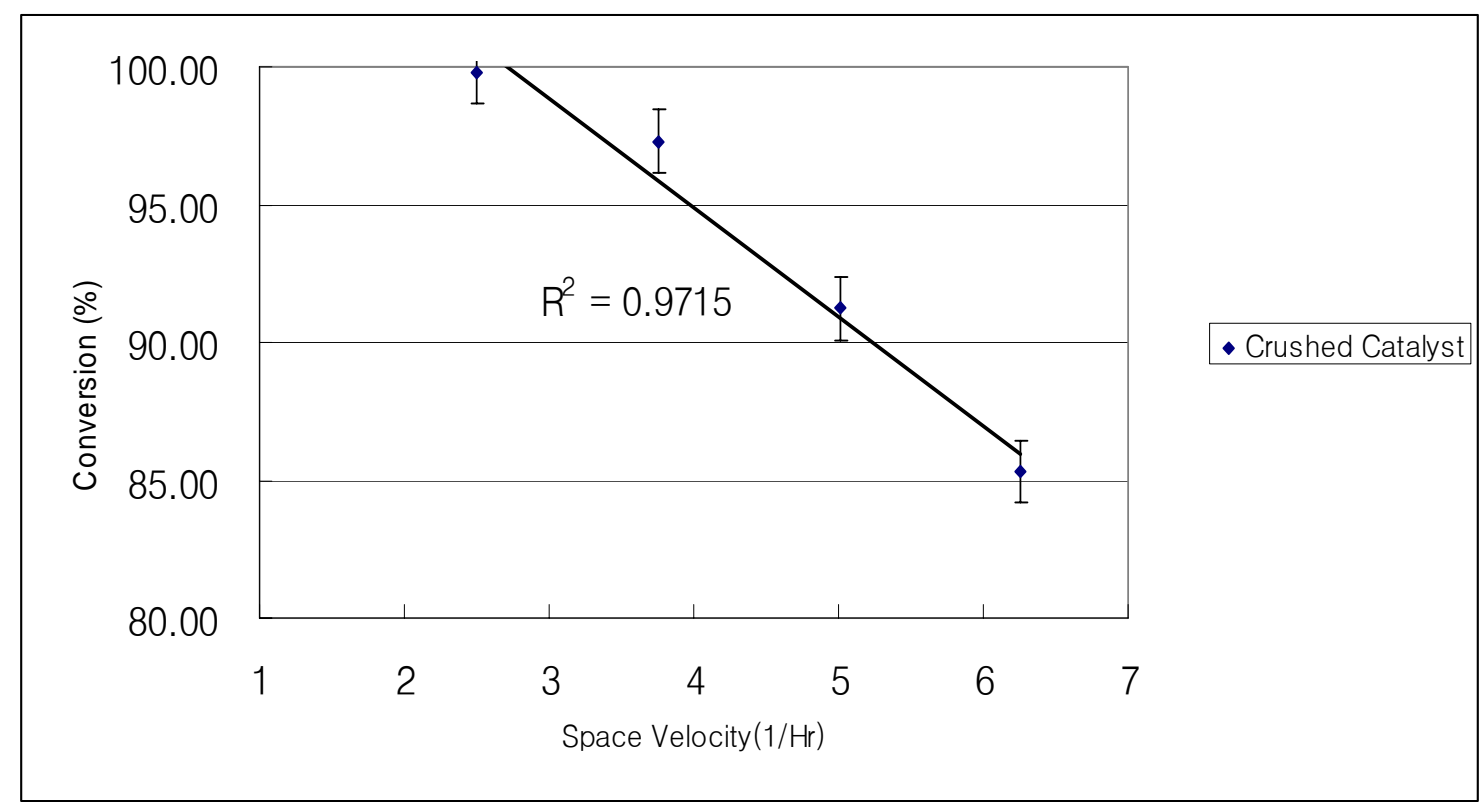

Figure 14 Overall Conversion versus Space Velocity Using Coal-derived Methanol

Table 5 shows results of a 70 hour catalyst degradation test. This experiment was performed using reactor C. Again, 39g crushed catalyst was used for this experiment. 2.5 Liquid hourly space velocity of methanol (LHSV-M) was maintained for 70 hours and data points were taken approximately every two hours.

Table 5 Results of catalyst degradation test for 70 hours

\begin{tabular}{|l|l|l|l|l|l|}
\hline Data Point & Time(Hours) & Condensation $(\mathrm{g})$ & Premix used $(\mathrm{g})$ & Density $\left(\mathrm{kg} / \mathrm{m}^{3}\right)$ & Conversion $(\%)$ \\
\hline 1 & 3.833 & 38.5 & 212.3 & 0.9959 & 99.96 \\
\hline 3 & 6.5 & 52.7 & 237.7 & 0.996 & 99.98 \\
\hline 4 & 9.5 & 59.6 & 318 & 0.9958 & 0.9956 \\
\hline 5 & 12.5 & 59 & 314.3 & 0.9954 & 99.93 \\
\hline 6 & 15.5 & 59.2 & 311.2 & 0.9953 & 99.84 \\
\hline 7 & 17.5 & 38.9 & 202.8 & 0.9979 & 0.9948 \\
\hline 8 & 19.5 & 38.8 & 202.1 & 0.9945 \\
\hline 9 & 21.5 & 38.3 & 201.9 & 0.9942 \\
\hline 10 & 23.5 & 38.7 & 201.5 & 0.9942 \\
\hline 11 & 25.5 & 38.9 & 203.2 & 0.9936 \\
\hline 12 & 27.5 & 38.9 & 201.1 & 99.79 \\
\hline 13 & 29.5 & 39 & 202.2 & 99.63 \\
\hline 14 & 31.5 & 38.5 & 202 & 99.56 \\
\hline 15 & 33.5 & 37.8 & 204.9 & 99.56 \\
\hline 16 & 35.5 & 40.5 & 195.9 & 99.42 \\
\hline
\end{tabular}




\begin{tabular}{|l|l|l|l|l|l|}
\hline 17 & 39.5 & 41.4 & 197.6 & 0.9922 & 99.02 \\
\hline 18 & 41.5 & 39.3 & 200 & 0.992 & 99.02 \\
\hline 19 & 43.5 & 39.5 & 199.1 & 0.9916 & 98.92 \\
\hline 20 & 45.5 & 39.3 & 201.3 & 0.9913 & 98.87 \\
\hline 21 & 47.5 & 39.6 & 200.9 & 0.9912 & 98.84 \\
\hline 22 & 49.5 & 38.6 & 199.4 & 0.991 & 98.81 \\
\hline 24 & 51.5 & 39.9 & 200.7 & 0.997 & 98.71 \\
\hline 25 & 53.5 & 39.6 & 199.2 & 0.9901 & 98.57 \\
\hline 26 & 55.5 & 38 & 204.4 & 0.99 & 98.64 \\
\hline 27 & 57.5 & 40.2 & 191.9 & 0.9902 & 98.51 \\
\hline 28 & 60 & 50.3 & 233.9 & 0.9899 & 98.4 \\
\hline 30 & 62 & 39.3 & 200.3 & 0.9893 & 98.4 \\
\hline 31 & 64 & 39.3 & 197.1 & 0.9893 & 98.37 \\
\hline 32 & 66 & 40 & 200.9 & 0.9894 & 98.4 \\
\hline
\end{tabular}

Error band at space velocity 2.5 (See Figure 14) is 0.7613 . It can definitely indicate when catalyst degradation starts in the reactor. After 30 hours (See Figure 15), catalyst degradation started approximately $-0.0292 \% / \mathrm{hr}$ rate.

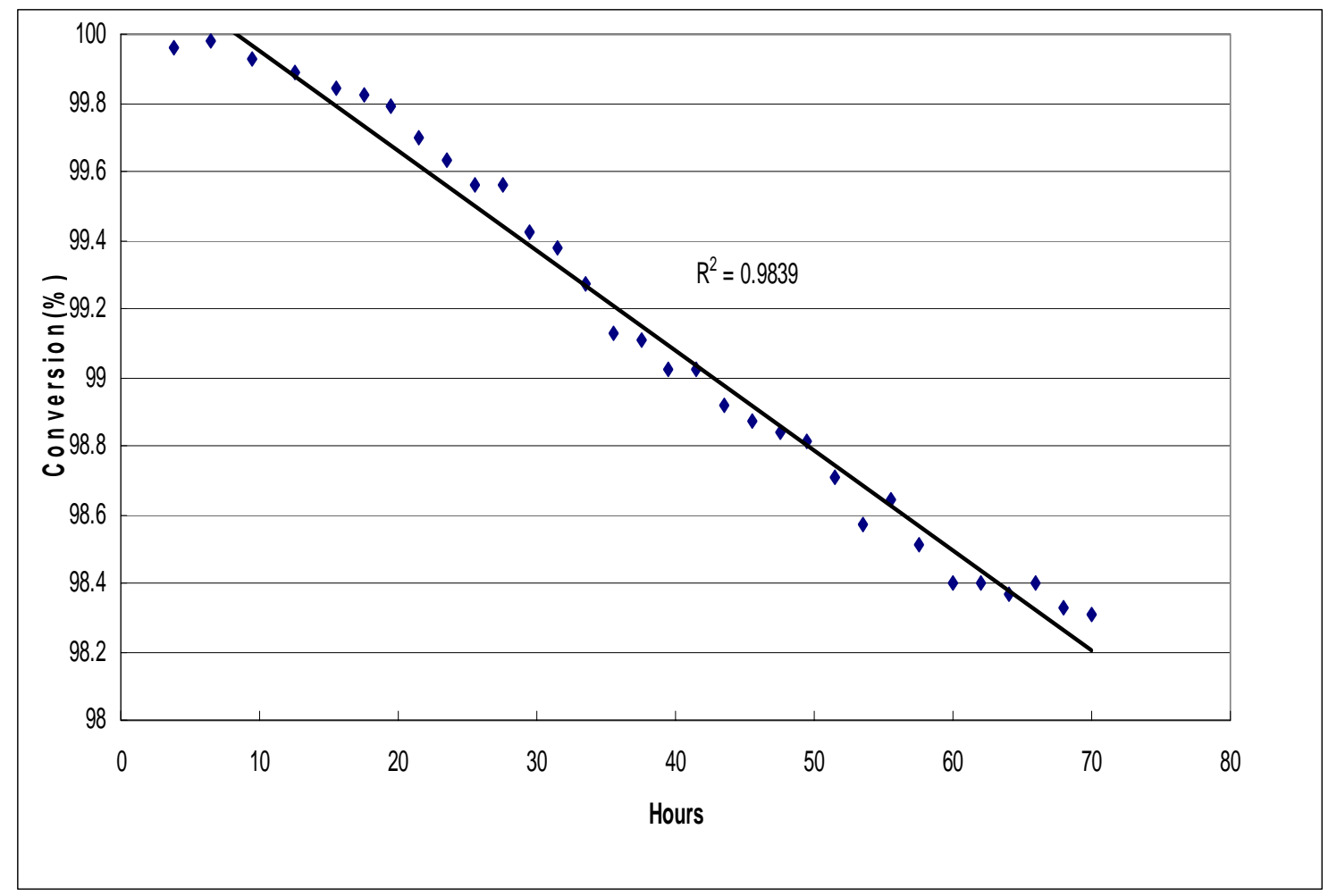

Figure 15 Conversion versus time for 70 hours (2.5 LHSV-M) 


\section{Steam Reformation Enhancement Methods}

So far, the data points of $2 \mathrm{P}, 2 \mathrm{C}, 8 \mathrm{P}$ and $8 \mathrm{C}$ were already collected. The conversion results are tabulated in Table 6 .

Table 6 -Experiment Results (*2P stands for 2 packs of pelletized catalyst and 2C for 2 packs of crushed catalyst)

\begin{tabular}{|l|l|l|l|l|l|l|l|l|}
\hline $\begin{array}{l}\text { Exp. } \\
\text { Config. }\end{array}$ & $\begin{array}{l}\text { Flow } \\
\text { Rate } \\
(\mathrm{X} 1)\end{array}$ & $\begin{array}{l}\text { Catalyst } \\
\text { Dimension } \\
(\mathrm{X} 2)\end{array}$ & $\begin{array}{l}\text { Pack } \\
\text { Density } \\
(\mathrm{X} 3)\end{array}$ & $\begin{array}{l}\text { Trial } \\
1\end{array}$ & $\begin{array}{l}\text { Trial } \\
2\end{array}$ & $\begin{array}{l}\text { Trial } \\
3\end{array}$ & $\begin{array}{l}\text { Average } \\
\text { Conversion } \\
(\%)(\mathrm{Y})\end{array}$ & $\begin{array}{l}\text { Standard } \\
\text { Deviation }\end{array}$ \\
\hline 2P* & - & + & - & 97.76 & 97.1 & 96.95 & 97.27 & 0.43 \\
\hline $8 \mathrm{P}$ & - & + & + & 98.69 & 98.71 & 98.48 & 98.63 & 0.13 \\
\hline 2P & + & + & - & 62.21 & 61.62 & 61.64 & 61.82 & 0.34 \\
\hline $8 \mathrm{P}$ & + & + & + & 71.41 & 68.33 & 68.47 & 69.40 & 1.74 \\
\hline 2C & - & - & - & 99.8 & 99.74 & 99.74 & 99.76 & 0.03 \\
\hline $8 \mathrm{C}$ & - & - & + & 99.79 & 99.79 & 99.81 & 99.8 & 0.01 \\
\hline 2C & + & - & - & 79.43 & 79.06 & 78.9 & 79.13 & 0.11 \\
\hline $8 \mathrm{C}$ & + & - & + & 73.72 & 73.29 & 73.5 & 73.5 & 0.15 \\
\hline
\end{tabular}

Table 7 also shows the conversions results without implementing any bluff body ( $0 \mathrm{C}$ and $0 \mathrm{P})$ inside the reactor:

Table 7 -Conversion without bluff body

\begin{tabular}{|l|l|l|l|l|}
\hline $\begin{array}{l}\text { Exp. } \\
\text { Config. }\end{array}$ & $\begin{array}{l}\text { Flow } \\
\text { Rate } \\
\text { (X1) }\end{array}$ & $\begin{array}{l}\text { Catalyst } \\
\text { Dimension } \\
\text { (X2) }\end{array}$ & $\begin{array}{l}\text { Pack } \\
\text { Density } \\
\text { (X3) }\end{array}$ & $\begin{array}{l}\text { Average } \\
\text { Conversion } \\
(\%)\end{array}$ \\
\hline 0P & - & + & 0 & 97.29 \\
\hline 0P & + & + & 0 & 54.55 \\
\hline 0C & - & - & 0 & 99.42 \\
\hline 0C & + & - & 0 & 73.72 \\
\hline
\end{tabular}

From these data points, a preliminary statistical analysis has been done for this factorial experiment. Table 8 gives the overall average conversion $(\mathrm{Y})$, pooled deviation $\left(\sigma_{\mathrm{p}}\right)$, standard error $\left(\mathrm{S}_{\mathrm{E}}\right)$, and total degrees of freedom.

Table 8

\begin{tabular}{|l|l|l|ll|}
\hline $\begin{array}{l}\text { Overall Average } \\
\text { Conversion (\%) }\end{array}$ & $\begin{array}{l}\text { Pooled Standard } \\
\text { Deviation }\end{array}$ & Standard Error & $\begin{array}{l}\text { Total Degrees of } \\
\text { Freedom }\end{array}$ \\
\hline 84.91 & 0.6577 & 0.2685 & 16 & \\
\hline
\end{tabular}

The method to calculate the correlation effects of these variables is taking the average of the average conversion outputs when the variable or sets of variables were high and subtracting the same average when the variable or sets of variables were low. This statement can be simplified as following equation: 
$E_{i}=\frac{\sum_{\text {Run }=1}^{8} Y_{r u n} \cdot X_{i, \text { run }}}{4}$

Equation 1

Where $X_{i}=+1$ for high level and $X_{i}=-1$ for low level.

Interactions can be found in a similar manner by replacing $\mathrm{X}_{\mathrm{i}}$, run with the multiplication of $X_{i, \text { run }}$ and $X_{j, \text { run. }}$. The interaction is tabulated in Table 9.

Table 9 - The effects and interactions found from the factorial experimentation.

\begin{tabular}{|l|l|}
\hline Effect of Flow Rate $\left(\mathrm{E}_{1}\right)$ & -27.90 \\
\hline Effect of Catalyst Dimension $\left(\mathrm{E}_{2}\right)$ & -6.27 \\
\hline Effect of Package Density of Bluff Bodies $\left(\mathrm{E}_{3}\right)$ & 0.84 \\
\hline Interaction of Flow Rate and Catalyst Dimension $\left(\mathrm{I}_{1,2}\right)$ & -4.44 \\
\hline Interaction of Catalyst Dimension and Package Density $\left(\mathrm{I}_{2,3}\right)$ & 0.14 \\
\hline Interaction of Flow Rate and Package Density $\left(\mathrm{I}_{1,3}\right)$ & 0.43 \\
\hline Interaction of Flow Rate, Catalyst Dimension and Package Density $\left(\mathrm{I}_{1,2,3}\right)$ & 2.97 \\
\hline
\end{tabular}

After an uncertainty analysis, the signal-to-noise t-ratio was calculated using Equation 2.

$t^{*}=\frac{E \text { or } I}{S_{E}}$

Equation 2

The signal-to-noise t-ratio of each variable and the Student-t value at $95 \%$ and $99.9 \%$ confidences were tabulated in Table 10.

Table 10 - Signal-to-noise t-ratios and statistical significance

\begin{tabular}{|l|l|l|l|}
\hline $\begin{array}{l}\text { Student t-value at 95\% Confidence }=2.120 \\
\text { Student t-value at 99.9\% Confidence }=4.015\end{array}$ & $\mathrm{t}^{*}$ & $\begin{array}{l}\text { Significant at } \\
95 \% \\
\text { Confidence? }\end{array}$ & $\begin{array}{l}\text { Significant at } \\
99.9 \% \\
\text { Confidence? }\end{array}$ \\
\hline Effect of Flow Rate $\left(\mathrm{E}_{1}\right)$ & -103.9 & Yes & Yes \\
\hline Effect of Catalyst Dimension $\left(\mathrm{E}_{2}\right)$ & -23.34 & Yes & Yes \\
\hline Effect of Package Density of Bluff Bodies $\left(\mathrm{E}_{3}\right)$ & -3.12 & Yes & No \\
\hline $\begin{array}{l}\text { Interaction of Flow Rate and Catalyst } \\
\text { Dimension }\left(\mathrm{I}_{1,2}\right)\end{array}$ & -16.52 & Yes & Yes \\
\hline $\begin{array}{l}\text { Interaction of Catalyst Dimension and Package } \\
\text { Density }\left(\mathrm{I}_{2,3}\right)\end{array}$ & 0.52 & No & No \\
\hline $\begin{array}{l}\text { Interaction of Flow Rate and Package Density } \\
\left(\mathrm{I}_{1,3}\right)\end{array}$ & 15.03 & Yes & Yes \\
\hline Interaction of All Three $\left(\mathrm{I}_{1,2,3}\right)$ & 11.07 & Yes & Yes \\
\hline
\end{tabular}

By comparing the signal-to-noise t-ratios with Student-t values of each variable's effect and their interaction, the result indicates a statistically significant effect of the influence on package density at $95 \%$ confidence. It was also expected to have significant effect at $99.9 \%$ but the result didn't show as what was expected. The cause might because the 
volume of 8 package crushed catalyst bed affects the result but not sure. A second or more runs are required to confirm the result.

Figure 16 and Figure 17 compare the fuel conversion versus liquid hourly space velocity of methanol in different package density using crushed (Figure 16) and pelletized (Figure 17) catalysts.

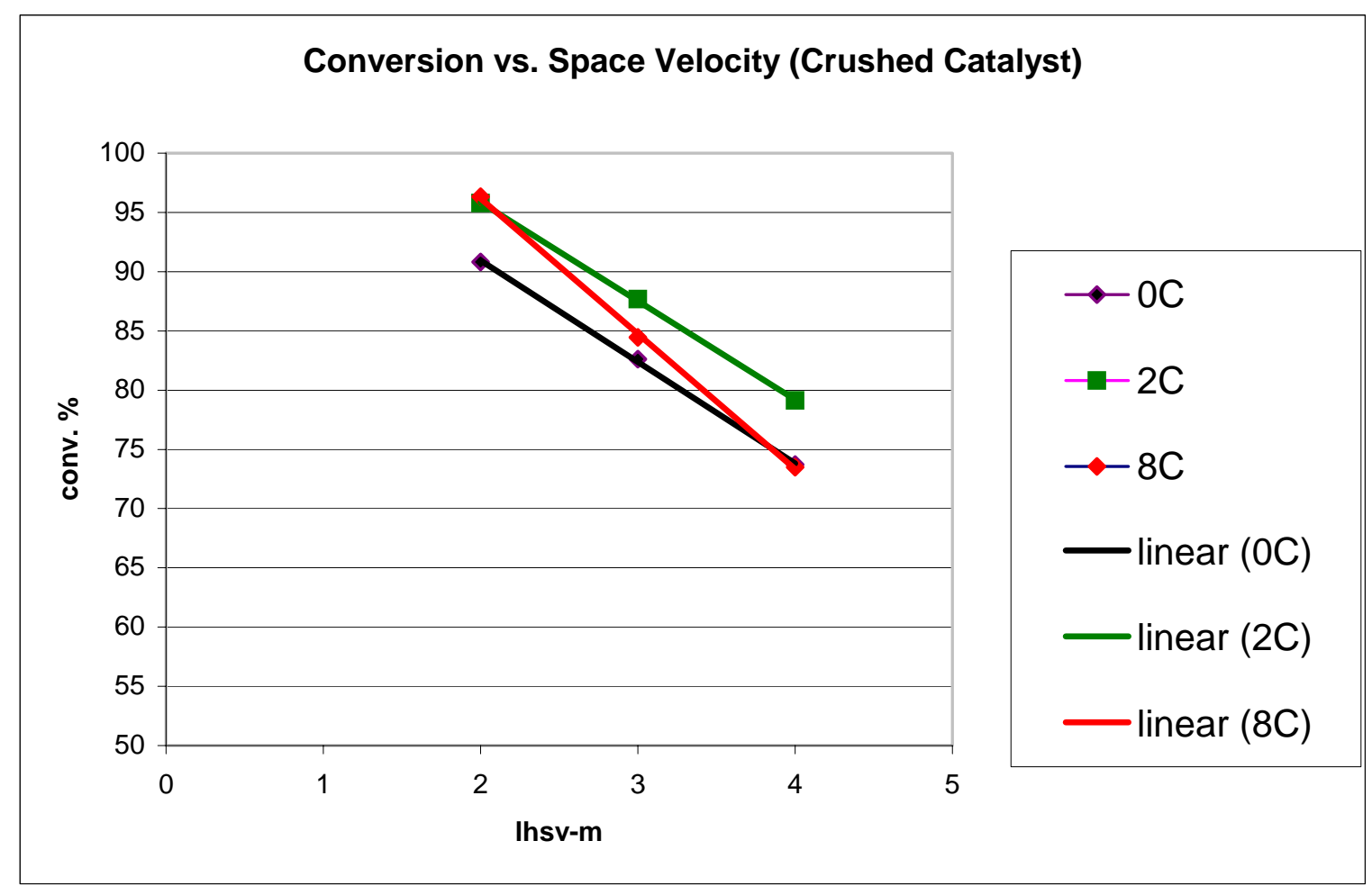

Figure 16 - Conversion vs. Liquid Hourly Space Velocity of Methanol (crushed catalyst) 


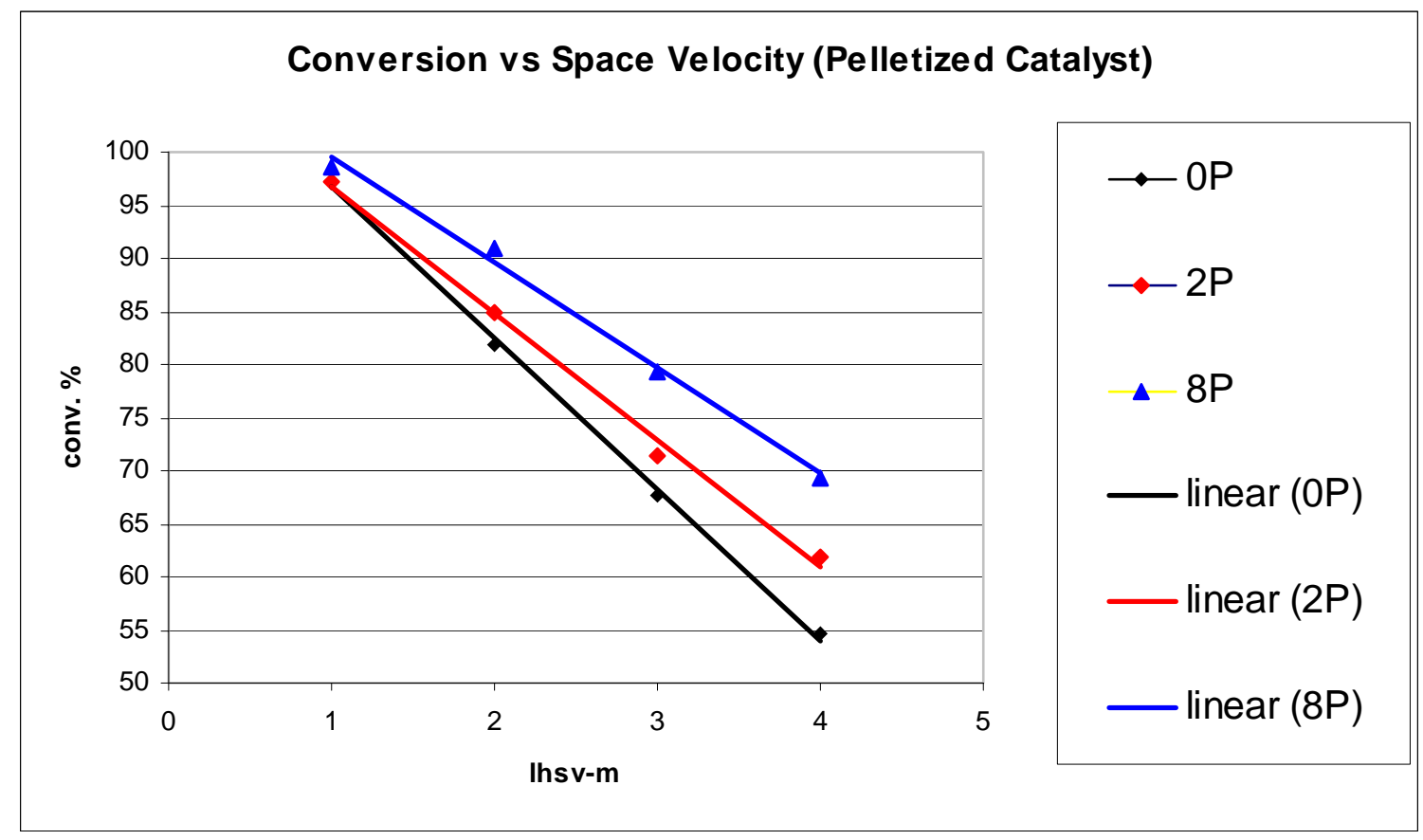

Figure 17 - Conversion vs. Liquid Hourly Space Velocity of Methanol (pelletized catalyst)

In crushed catalyst runs, even though a 2-package bluff body raises the fuel conversion for about 5\% compared to one without bluff body, an 8-package density instead has a lower conversion as that with no bluff body when increasing the flow rate. This result indicates that a higher package density ( 8 packages) might not have a better conversion for high space velocity. But from the extension of its trend line, it seems can have a 99\% conversion with a higher space velocity compare to 2 package and no package ones. This hypothesis still requires more data at those space velocity points and further investigation to substantiate. Also, 4-package and 6-package data points will also be taken to find out the optimizing performance for bluff bodies.

When loading the crushed catalyst into an 8-package bluff body reactor, the volume of the bed catalyst has a large fluctuation (up to 1.5 cubic inch) for a same mass of catalyst (250 grams) compare to pelletized catalyst. This unexpected volume change in different catalyst size is considered to affect the space-velocity and the overall conversion. Therefore it is required to take a $2^{\text {nd }}$ or more runs to confirm the result.

In pelletized catalyst, the chart shows an obviously increase of fuel conversions between 8-package density, 2-package density and 0-package density. Also, increasing the space velocity does increase the conversion for $7.5 \%$ between 8-package and 2package density and $15 \%$ compare to 0-package density. This result has a contrary performance with crushed catalyst. A further investigation in heat transfer and mass transfer study will be taken to explain this interesting phenomenon. Besides this, 4package and 6-package pelletized data points will also be taken to analysis more detail relationship between the package density and conversion. 


\section{CONCLUSION}

The second round of external methanol evaluation is complete. The second round of test results showed a similar order of magnitude for the coal-based and the fuel cell grade methanols regarding chlorides and sulfur.

Construction of the autothermal reformer (ATR) is now completed and preliminary testing has begun. The initial tests have begun with a catalytic converter grade catalyst to validate the test procedures and to give the research team valuable experience with analyzing both the data and control schemes. Once start-up, operation and shut-down procedures have been tested and validated, data collection will proceed using a specially designed proprietary catalyst specifically designed for autothermal reformation.

Further investigations into methods of enhancing the heat transfer characteristics were also performed. Additionally, catalyst degradation studies have begun using coal-derived methanol.

Steam reformation of coal-derived methanol continues. Due to a careful evaluation of the steam reformer temperature profile it was determined that significant sheath conduction from the wall was biasing the temperature measurements close to the reactor wall. A new thermocouple design utilizing a miniature sheath embedded into an external housing with insulating material was tested. This new thermocouple design had more reliable results than the standard design for determining an accurate temperature profile. This new thermocouple design is being implemented throughout the reactor and also into the ATR reactor.

Data has been collected showing enhancement of heat transfer and mass transfer by bluff bodies. This data is being analyzed and is being expanded to include an empirical model of the enhancement process. Several packing densities are being evaluated in steady state with the bluff bodies. Results are very encouraging to the research team and show significant enhancement of conversion.

In addition to the above projects catalyst degradation projects have been started. The catalyst degradation study will monitor conversion while operating in steady state for the two methanol fuels. This catalyst degradation study will expand as data become available.

Several projects are scheduled for the next quarter including further ATR reactor development and testing, continued evaluation of coal-based methanol in the steam reformers, validation of heat transfer enhancement methods by use of bluff bodies and measuring catalyst degradation using the various methanols. A trip to the DOE sponsor is being planned for September to present the annual results. 


\section{REFERENCES}

[1] Erickson, P.A., Enhancing the Steam-Reforming Process with Acoustics: An Investigation for Fuel Cell Vehicle Applications, doctoral dissertation, University of Florida, Gainesville, FL, 2002 